\title{
“Free Complete Articles": Where are they?
}

\author{
Abhimanyu Rohmetra ${ }^{1 *}$, Ankita Jaiswal ${ }^{2}$, Ishita Gupta ${ }^{3}$ \\ ${ }^{1}$ Department of Orthodontics \& Dentofacial Orthopedics, Saraswati Dental College, India \\ ${ }^{2}$ Private Practitioner, India \\ ${ }^{3}$ Institute of Dental Science, India
}

Submission: October 26, 2016; Published: December 04, 2017

*Corresponding author: Abhimanyu Rohmetra, MDS, Department of Orthodontics \& Dentofacial Orthopedics, Saraswati Dental College, India, Email: dr.rohmetra@gmail.com

\section{Abstract}

References form the backbone of any dental literature. Presently, because of high inflation, it is very difficult for any library/organization/ college to purchase all journals. The condition is even worse for an individual person, such as private practitioners and dental students. The answer lies in the free availability of full-text articles. The authors share their own experiences about the accessibility of articles which can be downloaded free.

Keywords: Free downloadable articles; Research work; Free complete articles

\section{Introduction}

Presently, in India only 304 dental colleges are providing undergraduate dental education in the form of BDS, 239 colleges are providing MDS degree in various dental specialties [1]. On comparing this data with number of research articles published, the latter stands in an ordinary situation. One of the cause responsible for the relatively few number of research publications, is unavailability of free complete articles. Research works, published by most of the journals, are paid. Many of the undergraduates or postgraduate students may not be able to purchase these high-cost journals or articles. In addition to this, many researchers are unwilling to spend any amount on journals. These are some of the situations where completely free full-text articles come for rescue, but many of the beginners all over the world may not be familiar about how to search these articles. In addition, free complete articles are the first choice for every of the postgraduate students for their dissertations.

\section{How to Approach}

In addition to journals which are fully Open Access, there are few other journals which operate through subscriptions as mainstream journals do, but which offer open access to the electronic versions of their articles after a delay of nearlya year, or selectively for few individual articles, provided the authors have paid an additional charge to "open-up" these selective articles [2]. Free articles can be assessed in the following ways.

\section{Medknow publications}

Medknow Publications publish around 150 journals. They provide free access to the electronic editions of all the journals [3].
Researchers just have to log on to the site www.medknow.com, fill the key word and search. Anyone can visit the search option, available in their journals site through www.journalonweb.com, insert the key word, and search across multiple journals. Most of the times, this site alone provides sufficient number of references required for the purpose. The important Dental journals published by Medknow Publications are The Journal of Indian Prosthodontic Society, Journal of Orthodontic Science, Journal of Orthodontic Research, International Journal of Orofacial Research, Saudi Journal of Oral Sciences [4].

\section{PubMed Central and PubMed}

PubMed Central is the United States National Library of Medicine's digital archive of biomedical and life sciences journals literature which gives free access to the full text of articles [5]. To search for free full-text articles in PubMed Central, one has to browse the site http://www.ncbi.nlm.nih.gov/pmc/, write the topic/author/journal title, and search across all articles.

PubMed is a database of abstracts and citations for articles from thousands of journals. PubMed does not include full-text journal articles [6]. It includes links to full-text articles at many journal web sites as well as to most of the articles in PubMed Central [7]. Here, articles can be searched on the site http://www. ncbi.nlm.nih.gov/pubmed. Search can be limited to contents free on web by using filter your results and clicking free full text.

\section{Directory of Open Access Journals}

The directory covers all open access scholarly and scientific journals that use a quality control system to guarantee the content. 
It provides articles from 81 Journals and covers 28350 articles of dentistry [8]. The disadvantage of directory of open access journals is that someof these journals are in languages other than English. Here, articles can be searched on the sitehttp://www. doaj.org.

\section{Google, Google Scholar, and Yahoo}

Yahoo search (http://www.search.yahoo.com) and Google (http://www.google.com) are two of the world's most hit web pages and two largest web-based search engines [9]. Usually these are the first search sites for scholars. They provide links for both paid and free articles. The disadvantage of these sites is that additionally they provide materials that may not give scholarly information. Most of the articles are repeated also. Here the catch is that one article which is paid at one web link may be free at another link. Google Scholar (http://www.scholar.google.com) gives a simple way to broadly search for the relevant scholarly literature and research [10].

\section{The Cochrane Library}

The Cochrane Library facilitates high-quality review articles. The Cochrane Database of Systematic Reviews has an impact factor of 6.22 in 2015 [11]. Articles can be searched on the site http://www.thecochranelibrary.com/view/0/index.html.

\section{Public library of science}

Public library of science (PLS) is a nonprofit organization of scientists and physicians committed to making the world's medical and scientific literature a freely available public resource [12]. Everything published on this site is free and easily available throughout the world, for researchers to read, download, copy, distribute, and use [13]. Articles can be searched here on the site https://www.plos.org/publications

\section{Free Medical Journals}

Currently, total 4832 journals are available on this site [14]. Among them, nearly 16 are journals are related to dentistry and all of them are in English [15]. Some journals are available only a few months after the release. Journals can be searched on the site. http://www.freemedicaljournals.com/f.php?f=ip_denti

\section{British dental association}

A wide range of free online medical and dental journals is available via PubMed central which indexes and provides links to more than 300 titles and DOAJ (Directory of Open Access Journals) which provides access to around 77 full text dental titles. All the articles and their link available are free [16]. Journals can be searched over https://www.bda.org/library/journals-articles/ free-online-journals

\section{Ortho café}

Along with free articles download provides MDS orthodontic question bank, topic wise [17] E-Books are also available free of cost. All material can be downloaded from ortho.fourthmolar. com/orthodontic-journals-free-download/

\section{Biomed central}

BioMed Central is a Science, Medicine, and Technology publisher. All original research articles published by BioMed Central are free and accessible online immediately upon publication [18]. After free registration, journals can be searched over http://www.biomedcentral.com/journals

\section{The website of Italian library association}

Here journals can be traced on the site http://www.aib.it/aib/ commiss/cnur/peb/pebd.htm [19]. This site provides both paid and free journal articles.

\section{Europe pubmed central}

Europe PubMed Central (PMC) is a full-text article database, having over 5 million more abstracts than PubMed that extends the functionality of the original PubMed Central (PMC) repository. Europe PMC has developed considerably since its inception in 2007 and now includes both PMC and PubMed search, as well as access to other records such as Patents, Agricola, , and recent biomedical theses. Europe PMC also differs from PubMed/PMC in that the abstract and full text can be searched in an integrated manner from one input box. All of the articles in Europe PMC are "Free Access," also not all content available in PMC is made available to Europe PMC [20].

\section{National library of medicine gateway}

National library of medicine also known as NLM is a webbased user-friendly system that searches not only MEDLINE but many other NLM databases at the same time. Articles can be searched here on https://www.nlm.nih.gov/

\section{Elsevier journals}

Some of the journals published by Elsevier provide free access to non subscribers, after a certain period of time has elapsed following the final publication [21]. The list of journals can be seen on websitehttps://www.elsevier.com/about/open-science/openaccess/open-access-journals

\section{Conclusion}

Free complete articles play a crucial role in updating the knowledge of dentists and researchers. They play key role in preparation of any thesis or manuscript, for the persons who is unable to subscribe to these articles due to some reason. These articles will be useful for such persons. Authors requests for the contribution of any other link for free complete articles, known by any reader.

\section{References}

1. [Last accessed on 2016 August 24]. Available from: http://www. dciindia.org.in/CollegeSearch.aspx?ColName $=\&$ Courseld

2. BjÖrk BC, Welling P, Laakso M, Majlender P, Hedlund T, et al. (2010) Open Access to the Scientific Journal Literature: Situation 2009. PLoS One 5(6): e11273. 
3. http://www.medknow.com

4. http://www.journalonweb.com

5. http://www.ncbi.nlm.nih.gov/pubmed?db+=+pmc+

6. http://www.ncbi.nlm.nih.gov/books/NBK3827/\#pubmedhelp.How to_Get_the_Journ

7. http://www.ncbi.nlm.nih.gov/pmc/about/faq/

8. https://doaj.org/subjects

9. Jain V, Raut DK (2011) Medical literature search dot com. Indian J Dermatol Venereol Leprol 77(2): 135-40.

10. http://www.scholar.google.com

11. ht t p : / / w w w.thecochranelibrary.com / vie w / 0 / AboutTheCochraneLibrary.html

12. https://www.plos.org/publications
13. https://www.plos.org/open-access

14. http://www.freemedicaljournals.com

15. http://www.freemedicaljournals.com/f.php?f=ip_denti

16. https://www.bda.org/library/journals-articles/free-online-journals

17. http://www.ortho.fourthmolar.com/tag/download

18. http://www.biomedcentral.com

19. http://www.aib.it/aib/commiss/cnur/peb/pebd.htm3

20. McEntyre J, et al. (2015) Europe PMC: a full-text literature database for the life sciences and platform for innovation., Nucleic Acids Res. (2015) 43 (Database issue): D1042-D1048.

21. https://www.elsevier.com/about/open-science/open-access/openaccess-journals

\section{Your next submission with Juniper Publishers} will reach you the below assets

- Quality Editorial service

- Swift Peer Review

- Reprints availability

- E-prints Service

- Manuscript Podcast for convenient understanding

- Global attainment for your research

- Manuscript accessibility in different formats

( Pdf, E-pub, Full Text, Audio)

- Unceasing customer service

Track the below URL for one-step submission https://juniperpublishers.com/online-submission.php 